\title{
Pengaruh terapi murottal terhadap denyut nadi dan pernafasan pada bayi dengan berat badan lahir rendah
}

\author{
Hamid Mukhlis ${ }^{1^{*}}$; Marini $^{2}$ \\ Rumah Sakit Umum Daerah (RSUD) Kota Agung \\ e-mail: $\underline{\text { me@hamidmukhlis.id }}^{1 *)}$; marini.stikes@gmail.com ${ }^{2}$
}

\begin{abstract}
Abstrak. Penurunan Angka Kematian Ibu (AKI) dan Angka Kematian Bayi (AKB) di Indonesia masih jauh dari target yang harus dicapai. AKB baru lahir di Indonesia mencapai 35 per 1000 kelahiran hidup. Bayi dengan Berat Badan Lahir Rendah (BBLR) merupakan salah satu penyebab kematian pertama pada bayi baru lahir di Provinsi Lampung. Penelitian ini bertujuan untuk mengetahui pengaruh terapi murottal terhadap kestabilan denyut nadi dan pernafasan pada bayi dengan BBLR di Rumah Sakit Umum Daerah Kotaagung. Desain penelitian menggunakan quasi eksperiment dengan pretest-posttest without control group. Subjek penelitian sebanyak 12 bayi dengan BBLR. Tehnik sampling dengan menggunakan consecutive sampling. Kelompok eksperimen mendapatkan terapi murottal Surat Ar Rahman dengan durasi 60 menit selama 3 hari dengan menggunakan speaker active kekuatan bunyi 50-60 dB. Analisis data menggunakan uji statistik paired t-test. Hasil penelitian menunjukkan penurunan rerata denyut nadi sebelum dan setelah treatmen didapatkan mean 161,50 dan 151,60 dengan nilai $p$ value 0,001 ( $p<0,05$ ). Penurunan rerata pernafasan sebelum dan setelah treatmen didapatkan mean 67,00 dan 58,50 dengan $p$ value 0,001 ( $p<0,05)$. Terapi murottal berpengaruh terhadap frekuensi denyut nadi dan pernafasan bayi dengan berat badan lahir rendah. Terapi murottal dapat digunakan sebagai alternatif treatmen didalam terapi keperawatan komplementer dalam memberikan asuhan keperawatan bayi di ruang perinatologi.
\end{abstract}

Keywords: Murottal; berat badan lahir rendah; Bayi baru lahir

\section{Pendahuluan}

Berat badan lahir rendah (BBLR) merupakan masalah kesehatan yang sering dialami pada sebagian besar masyarakat yang ditandai dengan berat lahir yang kurang dari 2500 gram. Kejadian BBLR pada dasarnya berhubungan dengan kurangnya pemenuhan nutrisi pada masa kehamilan ibu dan hal ini berhubungan dengan banyak faktor dan lebih utama pada masalah perekonomian keluarga sehingga pemenuhan kebutuhan konsumsi makanan pun kurang. Namun kejadian BBLR juga dapat terjadi tidak hanya karena aspek perekonomian, dimana kejadian BBLR dapat saja terjadi pada mereka dengan status perekonomian yang cukup. Dan hal ini terkait adanya pengaruh dari berbagai faktor yang mencakup usia, paritas, kadar haemoglobin dan pemanfaatan pelayanan antenatal (Manuaba, 2010).

Menurut data yang diperoleh dari Dinas Kesehatan Kabupaten Tanggamus pada tahun 2011 jumlah bayi yang dilahirkan hidup adalah 12.006 bayi, yang terdiri atas 6.133 bayi laki-laki (51,1\%) dan 5.873 bayi perempuan $(48,9 \%)$ serta terjadi $77(0,64 \%)$ kasus kematian. Penyebab kematian teratas masih di tempati BBLR dengan jumlah 25 kasus (32,5\%) diikuti asfiksia 18 kasus (23,4\%), kelainan kongenital 9 kasus(11,7\%), penyakit infeksi 7 kasus(9,1\%), pneumoni 3 kasus (3,9\%) dan penyebab lainnya sebanyak 15 kasus $(19,4 \%)$. Untuk kelahiran BBLR sendiri setiap tahun mengalami peningkatan. Pada tahun 2010 
ada 182 kasus, tahun 2011 sebanyak 197 kasus dan pada tahun 2012 sebanyak 290 kasus (Profil Kabupaten Tanggamus,2014).

Metode perawatan bayi BBLR yang sudah dikenal dan banyak digunakan adalah perawatan dengan metode kanguru. Padahal saat ini telah banyak studi penelitian yang mengembangkan terapiterapi keperawatan komplementer diantaranya terapi suara dengan menggunakan murottal maupun musik yang dapat mengurangi kecemasan, penelitian tersebut banyak dilakukan pada pasien juga janin pada ibu hamil. Manfaat terapi komplementer pada bayi prematur ini telah dibuktikan dalam beberapa penelitian yang telah dilaksanakan.

Terapi murottal yaitu dengan mendengarkan bacaan ayat-ayat Alqur'an. Dr. Al Qadhi, berhasil membuktikan bacaan Alquran berpengaruh besar hingga 97\% dalam melahirkan ketenangan jiwa dan penyembuhan penyakit. Dalam laporan sebuah penelitian disebutkan bahwa Alquran terbukti mampu mendatangkan ketenangan sampai $97 \%$ bagi mereka yang mendengarkannya, juga memberikan pengaruh besar jika diperdengarkan kepada bayi.

Hal senada juga diungkapkan oleh Dr. Nurhayati dari Malaysia dalam "Seminar Konseling dan Psikoterapi Islam" di Malaysia pada 1997. Menurut penelitiannya, bayi berusia 48 jam yang diperdengarkan ayat-ayat Al-Quran dari tape recorder menunjukkan respons tersenyum dan menjadi lebih tenang. Rumusan masalah penelitian adalah "Pengaruh Terapi Murottal Terhadap Denyut Nadi dan Pernafasan BBLR".

\section{Metode}

Jenis penelitian ini merupakan penelitian eksperimen yang bersifat kuantitatif dengan menggunakan desain penelitian quasi eksperiment pretest-posttest. Sebelum dan setelah melakukan tindakan terapi murottal terhadap bayi dilakukan pengukuran denyut nadi dan pernafasaan.

Populasi dalam penelitian ini adalah bayi yang dilahirkan dengan BBLR di Rumah Sakit Umum Daerah Kotaagung Kabupaten Tanggamus pada bulan Juli sampai Agustus 2015 sebanyak 12 orang. Responden adalah bayi yang memiliki berat badan lahir rendah dengan usia gestasi < 37 minggu (prematur) yang berada diruang Perinatologi Rumah Sakit Umum Daerah Tanggamus.

Penulis pada penelitian ini menggunakan non probability sampling dengan teknik sampling dalam penelitian ini adalah consecutive sampling yang berarti pemilihan sampel dengan menetapkan subjek yang memenuhi kriteria penelitian dimasukkan dalam penelitian sampai kurun waktu tertentu sehingga jumlah klien yang diperlukan terpenuhi (Sastroasmoro dan Ismail dalam Nursalam, 2013).

Pengambilan sampel yang digunakan dalam penelitian yaitu sampel yang memenuhi kriteria inklusi dan kriteria eksklusi. Dalam penelitian ini subyeknya adalah bayi BBLR yang di rawat di ruang Perinatologi dan subyek tersebut diambil dari keseluruhan populasi (total populasi) dalam kurun waktu dua bulan.

Pengolahan data melalui langkah-langkah editing, coding, processing dan cleaning. Penelitian ini menggunakan analisa univariat untuk menganalisa variabel-variabel yang ada secara deskripsi dengan menghitung distribusi frekuensi dan proporsinya untuk mengetahui karakteristik responden (jenis kelamin, usia gestasi, dan berat badan lahir).

Uji normalitas menggunakan Shapiro-Wilk test karena jumlah sampel kecil. Dari hasil uji normalitas data menunjukan data berdistribusi normal $(p>0,05)$ maka diuji dengan statistik parametrik. Dalam penelitian ini menggunakan paired t-test, uji ini untuk mengetahui perbedaan denyut nadi dan frekuensi pernapasan sebelum dan setelah dilakukan terapi murottal selama 3 hari. 


\section{Hasil Penelitian}

Berdasarkan tabel 1. jumlah responden berjenis kelamin laki-laki sebanyak lima orang (41.7\%) dan berjenis kelamin perempuan sebanyak tujuh orang (58.3\%) responden.

Tabel 1. Jumlah Responden Berdasarkan Jenis Kelamin pada Bayi BBLR

\begin{tabular}{lccc}
\hline & Jenis Kelamin & Jumlah & Persentase \\
\hline Laki-laki & & 5 & $41.7 \%$ \\
\hline Perempuan & Total & 7 & $58,3 \%$ \\
\hline \multicolumn{2}{c}{} & 12 & $100 \%$ \\
\hline
\end{tabular}

Tabel 2. Distribusi Responden Berdasarkan Masa Gestasi pada Bayi BBLR

\begin{tabular}{cccccc}
\hline Kategori & $\mathbf{N}$ & Median & SD & Min & Maks \\
\hline Umur & 12 & 32 & 2.563 & 28 & 34 \\
\hline BBL & 12 & 1800 & 258.78 & 1100 & 1900 \\
\hline
\end{tabular}

Tabel 2. menunjukkan rerata masa gestasi responden adalah 32 bulan dengan standar deviasi 2.563. Masa gestasi termuda adalah 28 bulan dan tertua adalah 34 bulan. Rerata berat badan bayi BBLR adalah 1800 gram dan berat badan bayi paling rendah adalah 1100 gram dan berat badan bayi paling tinggi adalah 1900 gram.

Tabel 3. menunjukkan distribusi nilai frekuensi denyut nadi dan pernapasan dari awal hingga evaluasi akhir. Dapat disimpulkan bahwa terjadi penurunan rata-rata nilai frekuensi denyut nadi pada hari pertama sebelum diberikan terapi 162 (SD 6,083) setelah responden diberikan intervensi hari pertama didapatkan nilai rata-rata denyut nadi 152 (SD 5,149) kemudian pada hari kedua didapat nilai rata-rata frekuensi denyut nadi sebelum terapi 165,5 (SD 7,620) setelah diberikan terapi murottal didapatkan nilai rata-rat frekuensi denyut nadi menjadi 160,00 (SD 5,753) kemudian pada hari ketiga sebelum diberikan terapi di dapatkan nilai rata-rata frekuensi denyut nadi 162,0 (SD 6,083) dan setelah diberikan terapi murottal didapatkan rerata frekuensi denyut nadi menjadi 155,0 (SD 5,878).

Frekuensi pernapasan pada hari pertama sebelum diberikan terapi 65 (SD 5,461), setelah responden diberikan intervensi didapatkan nilai rata-rata frekuensi pernafasan 60 (SD 4,502), kemudian pada hari kedua didapat nilai rata-rata frekuensi pernapasan sebelum terapi 65,00 (SD 5,461) setelah diberikan terapi murottal didapatkan nilai rata-rat frekuensi pernafasan menjadi 65,00 (SD 4,159) dan pada hari ketiga sebelum diberikan terapi di dapatkan nilai rata-rata frekuensi pernafasan 65,00 (SD 5,054), setelah diberikan terapi murottal rerata frekuensi pernpasan turun menjadi 59,0 (SD 4,232).

Uji normalitas menggunakan uji Shapiro-Wilk untuk mengetahui distribusi normal atau tidak. Data yang berdistribusi normal jika nilai $p$ value $\geq 0,05$.

Tabel 3. Distribusi Responden Berdasarkan Rata-Rata Denyut Nadi dan Pernafasan pada BBLR.

\begin{tabular}{lllcccc}
\hline Hari ke & \multicolumn{1}{c}{ Variabel } & Mean & Median & SD & Min & Maks \\
\hline \multirow{2}{*}{1} & Denyut nadi & 161,50 & 162,00 & 6,083 & 150 & 172 \\
& Pretest & 154,17 & 152,00 & 5,149 & 150 & 165 \\
\hline
\end{tabular}




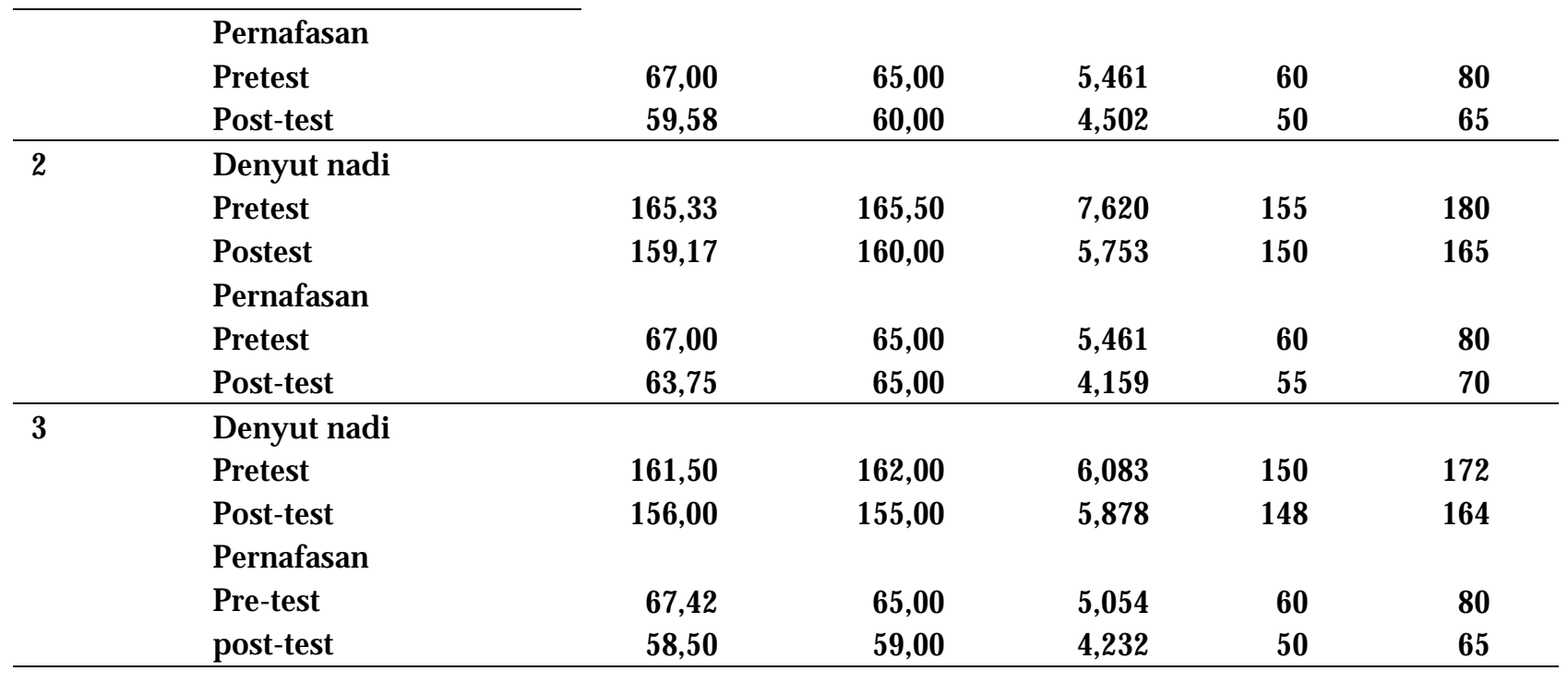

Tabel 4. Analisis Normalitas Data Responden

\begin{tabular}{lccc}
\hline & \multicolumn{3}{c}{ Shapiro-Wilk } \\
\cline { 2 - 4 } & Statistic & $d f$ & Sig. \\
\hline Frekuensi denyut nadi & & & \\
Pre-test & .959 & 12 & .771 \\
Post-test & .918 & 12 & .270 \\
\hline Frekuensi Pernafasan & & & \\
Pre-test & .875 & 12 & .075 \\
Post-test & .938 & 12 & .468 \\
\hline
\end{tabular}

Table 4. menunjukkan bahwa nilai $p$ value dari semua variabel yang akan dianalisis $\geq 0,05$ menggunakan uji Shapiro-Wilk sehingga dapat disimpulkan bahwa data penelitian ini terdistribusi normal dan dapat dilanjutkan melakukan uji hipotesis penelitian dengan menggunakan gunakan paired t-test.

Tabel 5. Pengaruh terapi murottal terhadap denyut nadi dan pernafasan pada BBLR.

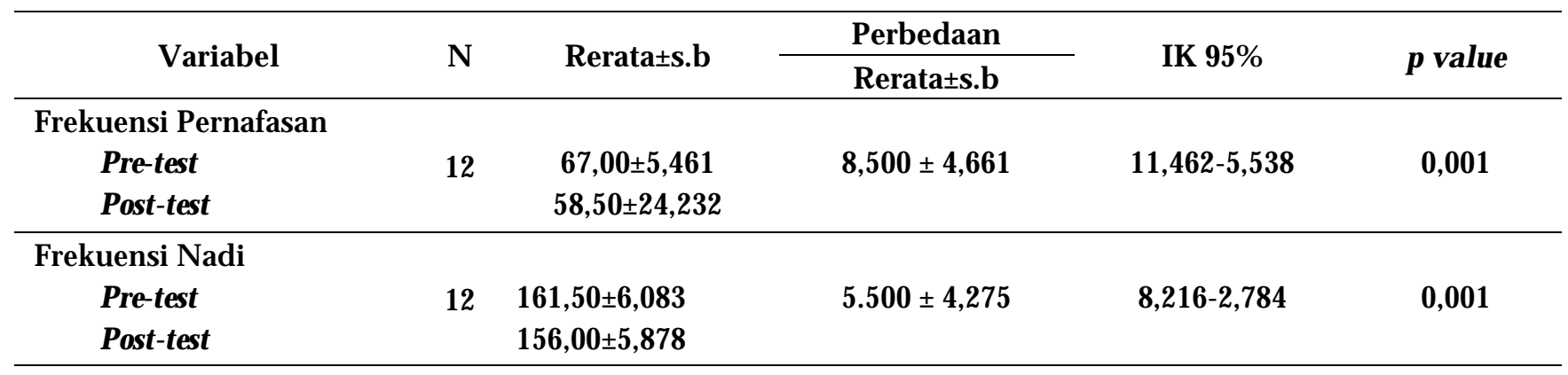

*Uji t berpasangan

Table 5. menunjukkan bahwa nilai signifikansi variabel frekuensi nadi $0,000(\mathrm{p} \varangle 0,05)$ yang menunjukkan bahwa terdapat perbedaan rata-rata skor frekuensi nadi bayi yang bermakna pada bayi BBLR sebelum dan sesudah diberikan terapi selama 3 hari berturut turut. Rerata skor frekuensi nadi 
sebelum diberikan terapi saat pretest 67,00 (SD 5,461) sedangkan setelah diberikan terapi posttest 58,50 (SD 24,232) dan memperoleh perbedaan rerata 8,50 point. Dari faktor peluang mampu menerangkan sebesar 0,00\% (5\%) maka hasil ini dianggap bermakna.

Sedangkan nilai significancy frekuensi pernapasan $0,001(\mathrm{p}<0,05)$ yang menunjukkan bahwa terdapat perbedaan rata-rata skor frekuensi pernapasan bayi yang bermakna pada bayi BBLR sebelum dan sesudah diberikan terapi selama 3 hari berturut turut. Rerata skor frekuensi pernapasan sebelum diberikan terapi saat pretest 161,50 (SD 6,083) sedangkan setelah diberikan terapi posttest 156,00 (SD $5,878)$ dan memperoleh perbedaan rerata 5,50 point. Dan dari faktor peluang juga mampu menerangkan sebesar 0,01\% (5\%) maka hasil ini dianggap bermakna.

Bayi baru lahir yang berat badannya saat lahir kurang dari 2500 gram (sampai dengan 2499). Bayi lahir rendah mungkin prematur (kurang bulan), mungkin juga cukup bulan (dismatur) (Saifuddin, 2006). Pada tahun 1961, WHO mengganti istilah bayi prematur dengan Bayi Berat Badan Lahir Rendah (BBLR) karena disadari tidak semua bayi dengan berat badan kurang dari 2500 gram pada waktu lahir adalah bayi prematur (Winkjosastro, 2006). Menurut Maryani (2013), bayi BBLR dibagi menjadi dua golongan yaitu : Prematuritas murni adalah bayi lahir dengan masa gestasinya kurang dari 37 minggu dan berat badannya sesuai dengan berat badan untuk masa gestasi itu atau disebut neonatus kurang bulan sesuai untuk masa kehamilan dengan manifestasi klinis berat badan kurang dari 2500 gram, panjang badan kurang dari $45 \mathrm{~cm}$ lingkar dada kurang dari 35sm, lingkar kepala kurang dari $33 \mathrm{~cm}$, masa gestasi kurang daru 37 bulan dan kepala lebih besar dari badan.

Bayi yang lahir dengan berat badan rendah sering terjadi komplikasi, berupa sindrom gawat nafas, dan peningkatan frekuensi denyut nadi, hal ini disebabkan oleh belum sempurnanya pembentukan membran hialin surfaktan paru yang merupakan suatu zat yang dapat menurunkan tegangan dinding alveoli paru. Dan sebagian alveoli menjadi kolaps, alveoli yang berperan sebagai tempat pertukaran oksigen dan karbon dioksida jumlahnya tidak cukup untuk memenuhi kebutuhan oksigen dalam darah. Dalam hal ini jantung berkompensasi untuk meningkatkan aliran darah unutk mencukupi kebutuhan oksigen jaringan. Hal ini menjadi salah satu penyebab mortalitas pada bayi yang terlahir dengan berat badan rendah. $\quad$ (Maryunani, 2013).

Kejadian sindrom gawat nafas yang terjadi pada kelahiran berat badan bayi rendah disebabkan oleh ketidak mampuan bayi beradaptasi dilingkungan luar rahim. Hal ini disebabkan berbagai faktor. Salah satu faktor adalah kematangan paru. Paru yang belum mencapai kematangannya saat dalam kehamilan tidak mampu memproduksi surfaktan salah satu zat yang dihasilkan epitel sel dalam alveoli untuk mencegah kolapsnya alveoli. Peningkatan frekuensi denyut jantung yang berkompensasi untuk mengatasi kekurangan kadar oksigen dalam darah. Bayi akan tampak pucat, bila kadar oksigen di jaringan perifer sangat rendah dan hal ini menyebabkan komplikasi di setiap organ dalam tubuh bayi.

Menurut peneliti kasus BBLR menjadi tanggung jawab bersama. Perlu kerjasama yang baik antara pemerintah dan masayarakat dalam pencegahan kasus ini. Pemerintah dalam hal ini diwakili oleh dinas kesehatan melalui puskesmas-puskesmas harus terus menggalakkan pendidikan kesehatan tentang BBLR, baik itu mengenai pencegahannya maupun perawatan di rumah bila ada keluarga dengan kasus bayi BBLR. Dan meningkatkan sarana di Rumah Sakit yang berkaitan dengan kasus BBLR baik itu sarana kelengkapan alat maupun keterampilan tenaga medis dan paramedis yang menangani masalah pada bayi BBLR serta mengembangkan berbagai metode keperawatan bayi BBLR. Hal ini bisa menurunkan angka kematian ibu dan bayi. Dari wawancara bebas dengan ibu yang melahirkan bayi dengan BBLR mengatakan tidak mengerti tentang BBLR.

Dari hasil penelitian setelah responden diberikan terapi murottal didapatkan nilai rata-rata denyut nadi 152 (SD 5,149). Hari kedua didapatkan nilai rata-rata frekuensi denyut nadi menjadi 160,00 (SD 5,753) dan pada hari ketiga didapatkan rerata frekuensi denyut nadi menjadi 155,0 (SD 5,878). Dan 
setelah responden diberikan intervensi hari pertama didapatkan nilai rata-rata frekuensi pernafasan 60 (SD 4,502) pada hari kedua nilai rata-rata frekuensi pernafasan menjadi 65,00 (SD 4,159) dan hari ketiga didapatkan rerata frekuensi pernpasan menjadi 59,0 (SD 4,232). Responden penelitian ini mengalami perubahan dalam respon fisiologisnya setelah diberikan terapi murottal selama 3 hari berturut-turut. Selama 60 menit terapi murottal berlangsung hampir semua responden terlihat rileks/tenang bahkan tertidur, ini dibuktikan setelah terapi murottal terdapat penurunan rata-rata frekuensi pernafasan dan frekuensi nadi pada BBLR. Ada 2 orang bayi yang menangis saat permulaan di intervensi tetapi setelah terapi murottal berlangsung sekitar 15 menit responden tampak tenang dan akhirnya tertidur.

Hal ini sejalan dengan ayat-ayat suci yang tercantum dalam Al-Quran bahwa terapi murottal adalah salah satu metode pengobatan yaitu dengan membacakan ayat-ayat Al Qur'an kepada pasien dan diulangi beberapa kali sampai terjadi proses penyembuhan, Insya Allah. Allah SWT menyampaikan kepada kita bahwa Al Qur'an itu adalah asy syifaa (penyembuh) : “Dan Kami telah menurunkan dari Alquran, suatu yang menjadi penawar (obat) dan rahmat bagi orang-orang yang beriman dan Alquran itu tidaklah menambah kepada orang-orang yang zalim selain kerugian" (Q.S.Al Isra : 82). Al Qur'anul karim memiliki pengaruh yang luar biasa terhadap tubuh, terutama pada sistem imunitas atau kekebalan tubuh. Dengan membaca Al Qur'an akan memperkuat tingkat kekebalan tubuh seseorang. Dan bahkan mampu mengembalikan keseimbangan sistem sel, terutama sel otak dan jantung, yang merupakan organ paling utama dalam tubuh manusia (Kahel, 2010).

Hal ini sejalan dengan penelitian yang dilakukan oleh Fikri yang melakukan penelitian yang berjudul Pengaruh Membaca al-Quran terhadap Tekanan Darah pada Lansia Hipertensi di Wilayah Kerja Puskesmas Ciputat Tahun 2012. Penelitian mengikut sertakan 28 orang responden dengan usia antara 50-75 tahun. 96,4\% berjenis kelamin perempuan dan 3,5\% berjenis kelamin laki-laki dan 100\% responden memilki IMT normal secara statistik memiliki varian yang sama. Hasil penelitian ini melaporkan penurunan tekanan darah sistol dan diastol pada kelompok interpensi $(\mathrm{p} \varangle 0,05)$ setelah melaporkan nilai perbedaan nilai tekanan darah yang signifikan antara kelompok intervensi $(p \varangle 0,05)$. Kesimpulan peneliti adalah ada pengaruh membaca Al-Quran terhadap penurunan tekanan darah pada lansia dengan hipertensi.

Menurut peneliti terapi murottal adalah salah satu upaya yang bisa sangat berguna dalam dunia kesehatan, terapi membacakan surat-surat Al quran terbukti menenangkan dan dapat menurunkan gelombang otak pada kondisi alpha pada fekuensi 7-12Hz. Dan dapat digunakan sebagai terapi selain obat. Pada bayi BBLR hal ini telah dibuktikan mampu menurunkan frekuensi pernafasan, dan frekuensi nadi bayi. Di harapkan setelah di berikan terapi murottal frekuensi denyut nadi dan pernafasan menurun dan menjadi lebih stabil yang berefek sirkulasi darah lebih baik sehingga bayi lebih tenang. Bila bayi tenang dan dapat tidur lebih nyenyak. Sehingga tidak banyak energi yang terbuang. Dengan kondisi tersebut diharapkan akan membantu kenaikan berat badan bayi.

Dari Hasil penelitian dapat dilihat nilai significancy variabel frekuensi pernafasan dengan nilai $\mathrm{p}$ value 0,000 ( $p \varangle 0,05$ ) yang menunjukkan bahwa terdapat perbedaan rata-rata skor frekuensi pernafasan bayi yang bermakna pada bayi BBLR sebelum dan sesudah diberikan terapi selama 3 hari berturut turut. Rerata skor frekuensi nadi sebelum diberikan terapi saat pretest 67,00 (SD 5,461) sedangkan setelah diberikan terapi posttest 58,50 (SD 24,232) dan memperoleh perbedaan rerata 8,50 point. Dari faktor peluang mampu menerangkan sebesar $0,00 \%$ (5\%) maka hasil ini dianggap bermakna. Sedangkan nilai significancy frekuensi denyut nadi $0,001(\mathrm{p} \varangle 0,05)$ yang menunjukkan bahwa terdapat perbedaan ratarata skor frekuensi denyut nadi bayi yang bermakna pada bayi BBLR sebelum dan sesudah diberikan terapi selama 3 hari berturut turut. Rerata skor frekuensi denyut nadi sebelum diberikan terapi saat pretest 161,50 (SD 6,083) sedangkan setelah diberikan terapi posttest 156,00 (SD 5,878) dan memperoleh 
perbedaan rerata 5,50 point. Dan dari faktor peluang juga mampu menerangkan sebesar 0,01\% (5\%) maka hasil ini dianggap bermakna.

Hasil penelitian ini sejalan dengan teori yang dikemukakan oleh Kahel (2010) Al Qur'anul karim memiliki pengaruh yang luar biasa terhadap tubuh, terutama pada sistem imunitas atau kekebalan tubuh. Dengan membaca Al Qur'an akan memperkuat tingkat kekebalan tubuh seseorang. Dan bahkan mampu mengembalikan keseimbangan sistem sel, terutama sel otak dan jantung, yang merupakan organ paling utama dalam tubuh manusia. Kemukjizatan $\mathrm{Al}$ Qu'an yang tidak bisa dicapai oleh sekedar ilmu sastra bahasa, ilmu alam semesta dan semacamnya. Al Qur'an memiliki kemujikzatan penyembuh (I'jaaz syifa'iy) yang begitu istimewa. Allah SWT telah memasukkan ke dalam ayat-ayat dalam kitabNya, informasi yang bisa menjadi jembatan kepada telinga, lalu ke otak kemudian mereinstall sel-sel saraf, serta memberi input data dan informasi yang benar kepadanya, hingga kemudian sel-sel itu bekerja secara optimal.

Otak dan jantung merupakan dua anggota tubuh yang Allah hamparkan untuk kita. Allah menitipkan kedua organ tubuh yang memiliki rahasia begitu luar biasa itu kepada kita Allah SWT menjadikan jantung sebagai pengarah otak dalam bekerja. Bahkan para ilmuwan menyingkap adanya unit sel saraf yang tidak berfungsi di dalam jantung lalu mempengaruhi kondisi tubuh secara keseluruhan.

Konferensi kedokteran Islam yang dilaksanakan di Amerika Utara pada tahun 1984 menghasilkan kesimpulan bahwa mendengarkan bacaan Al-Qur'an baik secara sengaja maupun tidak bisa mendatangkan ketenangan bagi jiwa sampai 98\%. Pembacaan Al-Qur'an secar tartil dan sesuai dengan kaidah tajwid memiliki kemampuan untuk memprogram ulang sel-sel otak sekaligus meningkatkan kemampuan (Abu salman, 2015). Dengan demikian terapi murottal dapat mempengaruhi frekuensi denyut nadi dan pernafasan pada bayi dengan berat badan lahir rendah.

Penelitian ini diperkuat oleh penelitian yang telah dilakukan sebelumnya oleh Zahrofi et al dengan judul penelitian Pengaruh Pemberian Terapi Murottal Al Quran Terhadap Tingkat Kecemasan Pada Pasien Hemodialisa Di RS Pku Muhammadiyah Surakarta Tahun 2013 terhadap 30 responden, dengan teknik sampling purposive sampling. Instrument penelitian berupa Hamilton Rating Scale for Anxiety (HRS-A). Analisis data hasil penelitian menggunakan uji Independent t-test dan Paired t-test. Kesimpulan dalam penelitian ini yaitu terdapat pengaruh pemberian terapi murottal Al-Qur'an terhadap tingkat kecemasan pasien hemodialisa di Rumah Sakit PKU Muhammadiyah Surakarta.

Menurut peneliti terapi murottal adalah salah satu terapi yang di ajarkan oleh nabi Muhammad Saw, atau pada zaman rosul disebut tibbun nabawi, walaupun belum dapat dilakukan penelitian yang menggunakan alat instrumen yang ilmiah, terapi murottal dapat dijadikan terapi alternatif penyembuh segala macam penyakit. Ayat alquran tidak dapat dibahas secara ilmiah karena hanya Allah sang pencipta yang Maha Mengetahui segalanya. Terapi dapat diterapkan di tempat-tempat pelayanan kesehatan, seperti puskesmas, praktek bidan, rumah sakit bahkan bisa disosialisasikan ke masyarakat. Setelah dilakukan penelitian dan didapatkan hasil bahwa terapi murottal ini dapat menurunkan frekuensi nafas dan nadi BBLR secara bermakna dengan nilai $\mathrm{p}$ value $\varangle$,05 dapat dibuktikan bahwa terapi efektif dijadikan sebagai terapi komplementer keperawatan islam.

Penelitian yang dilakukan masih memiliki beberapa keterbatasan. Adapun beberapa keterbatasan dalam penelitian ini yaitu jumlah responden dalam penelitian sedikit hanya terdapat 12 responden. Hal ini terjadi karena keterbatasan waktu dan jumlah kelahiran bayi BBLR prematur yang berada di RSUD Kotaagung pada rentang waktu 2 bulan jumlahnya sedikit. Peneliti tidak menggunakan kelompok kontrol. Hal ini juga karena keterbatasan waktu dan jumlah kelahiran bayi BBLR prematur. 


\section{Kesimpulan}

Penelitian ini membuktikan adanya perbedaan yang bermakna antara denyut nadi dan pernafasan pada bayi BBLR sebelum dan setelah pemberian terapi murottal. Dengan demikian terapi murottal berpengaruh secara bermakna terhadap denyut nadi dan pernafasan BBLR.

Terapi murottal dapat diterapkan di tempat-tempat pelayanan kesehatan, seperti puskesmas, praktek bidan, rumah sakit bahkan bisa disosialisasikan ke masyarakat. Setelah dilakukan penelitian dan didapatkan hasil bahwa terapi murottal ini dapat menurunkan frekuensi nafas dan nadi BBLR secara bermakna dengan nilai $\mathrm{p}$ value $\varangle 0,05$ dapat dibuktikan bahwa terapi efektif dijadikan sebagai terapi komplementer keperawatan islam.

Untuk peneliti selanjutnya dapat melibatkan lebih banyak responden serta menggunakan kelompok kontrol untuk meminialisir adanya ancaman validitas internal.

\section{Daftar Pustaka}

Abduldaem Al-Kaheel. (2010). Al Qur'an The Healing Book, Jakarta: Tarbawi Press.

Ahmad Warson Munawwi. (1984). Kamus Arab-Indonesia.

Abu Salman Farhan. (2015). Mukjizat Alqur'an yang Harus Diketahui Setiap Muslim. Jakarta: Mutiara Media

Bobak, I.M., Lowdermilk, D.L., Jensen, M.D. (2004). Keperawatan maternitas. Ed.4.Jakarta: EGC.

Dinas Kesehatan Kabupaten Tanggamus. (2011). Profil Kesehatan Tanggamus. Tanggamus

Dinas Kesehatan Propinsi Lampung. (2011). Profil Dinas Kesehatan Provinsi Lampung. Lampung

Dr. Jamal Elzaky. (2010). Terapi Baca AlQur'an. Jakarta: Zaman

Edi Sumardi. (2015). Terungkap, Inilah Manfaat Lain Membaca Alquran Bagi Tubuh. http:/makassar.tribunnews.com. di akses pada tanggal 1 juli 2015

Eskandari, N., Kezhavars, M., Ashayeri, H., Jahdi, F., Hosseini, F. (2012). Quran Recitation: Short-Term Effects and Related Factors in Preterm Newborns.

Faradisi, F. (2012). Perbedaan Efektifitas Pemberian Terapi Murotal dengan Terapi Musik Klasik terhadap Penurunan Tingkat Kecemasan Pada Pasien Pre Operasi Fraktur Ekstermitas di Rumah Sakit Dr.Moewardi Surakarta. Surakarta: FIK-UMS.

Fikri. (2012). Pengaruh Membaca al-Quran terhadap Tekanan Darah pada Lansia Hipertensi di Wilayah Kerja Puskesmas Ciputat Tahun 2012. http//deshowmustgoon.blogspot.com/2012/05/asuhankeperawatan-bayi-berat.html. Di akses tgl 24 januari 2015

http:/wawanislam.blogspot.com diakses pada tanggal 20 Februari 2015).

http://www.jurnal.stikes-aisyiyah.ac.id diakses pada tanggal 5- April-2015.

http://www.journal.stikesmuh-pkj.ac.id diakses pada tanggal 15-April-2015

Manuaba, Ida Ayu. (2010). Ilmu Kebidanan Penyakit Kandungan dan Keluarga Berencana untuk Pendidikan Bidan. 
Maryunani, A. (2009). Asuhan Kegawatdaruratan dan Penyulit pada Neonatus. TIM. Jakarta . (2013). Asuhan Bayi dengan Berat Badan Lahir Rendah. TIM. Jakarta

Muhammad Salim. (2013). Definisi Al Qur'an. http:/beritaislamimasakini.com. diakses pada tanggal 10 April 2015

Notoatmodjo, Soekidjo. (2010). Metodologi Penelitian Kesehatan. Jakarta: Rineka Cipta

Nursalam, (2013). Metodologi Pendidikan Ilmu Keperawatan”. Salemba Medika, Jakarta.

Rochjati, Poedji. (2003). “Skrining Antenatal pada Ibu Hamil”. Surabaya: Airlangga University Press

Saifuddin, A. B. (2006). "Buku Acuan Nasional Pelayanan Maternal Dan Neonatal". Jakarta: Yayasan Bina Pustaka.

Saif Al Battar. (2012). Penelitian Ilmiah Pengaruh Bacaan Al-Qur'an pada Syaraf, Otak dan Organ Tubuh Lainnya, Subhanallah, menakjubkan. http://www.arrahmah.com. Diakses pada tanggal 10 April 2015

Simbolon. (2012). Berat Lahir dan Kelangsungan Hidup Neonatal, Jurnal Kesehatan Masyarakat.

Sri Hananto Ponco Nugroho. (2014). Pengaruh Bacaan Al-Qur'an Terhadap Penyembuhan Luka Sirkumsisi di Balai Pengobatan Lamongan.

Winkjosastro. (2006). Ilmu Kebidana Edisi Ketiga. Jakarta: YBP-SP

Wong Dona, L. (2008). Buku Ajar Keperawatan Pediatrik Wong.Volume 1. Edisi 6. Jakarta: Penerbit Buku Kedokteran EGC

Yulia. (2013). Efektivitas Terapi Musik Klasik Mozart Terhadap Suhu Tubuh Bayi Prematur di Ruang Perinatologi di RSUD Banyumas.

Zahrofi et al. (2013). Pengaruh Pemberian Terapi Murottal Al Quran Terhadap Tingkat Kecemasan Pada Pasien Hemodialisa Di RS PKU Muhammadiyah Surakarta. 